\title{
MATERIAŁY
}

Patrycja Ziomek

DOI: 10.14746/BHW.2016.35.6

Instytut Historyczny

Uniwersytet Wrocławski

\section{Rola kobiety w okresie prenatalnym i pierwszych dniach życia dziecka w świetle XVIII-wiecznego poradnika Józefa Legowicza}

\begin{abstract}
The Role of Women in the Prenatal Period and First Days of a Child's Life in the Light of the Eighteenth-century Guidebook Written by Józef Legowicz

The author of the article presents how eighteenth-century writer Józef Legowicz sees the issue of motherhood. Józef Legowicz was a priest and a doctor of theology. He was a parson in Korkożyszki, a small village in Lithuania. He published 18 works, one of which was the guidebook Wedlock. He tried to show his parishioners the best way to achieve a harmonious marriage and raise children as good Christians. This guidebook is a valuable source of information about mother- and fatherhood in $18^{\text {th }}$ Century Poland. The main task of this article is to show the unique role of women in the early stages of a child's life.
\end{abstract}

Keywords: Józef Legowicz, guidebook, Poland $18^{\text {th }}$ Century

Status kobiety w dobie nowożytnej w całej Europie był stosunkowo niski. Maria Bogucka uważa, że to wynik deprecjacji pozycji niewiasty w społeczeństwach Starego Kontynentu związany z rozwojem: gospodarki wczesnokapitalistycznej, absolutyzmu i reformacji ${ }^{1}$. W okresie tym niewiasta nie była postrzegana w kategoriach autonomicznej jednostki, lecz patrzono na nią przez pryzmat płci, wieku, grupy społecznej, do której należała oraz jej stanu cywilnego. W XVIII w. Richard Steele sformułował definicję białogłowy w słowach: kobieta to córka, siostra, żona i matka - skromny dodatek do rodu meskiego ${ }^{2}$. Jej pozycja w rodzinie zależała od wielkości posagu wniesionego w małżeństwo oraz liczby dzieci (zwłaszcza synów), które wydała na świat. W Rzeczypospolitej Obojga Narodów status ten był nieco wyższy niż w przypadku innych państw europejskich, jednak i tak w kulturze staropolskiej kobiecie przypisane były trzy podstawowe

1 M. Bogucka, Białogłowa $w$ dawnej Polsce, Warszawa 1998, s. 5.

${ }^{2}$ H. Dziechcińska, Kobieta w życiu i literaturze XVI i XVII wieku, Warszawa 2001, s. 12. 
role życiowe: matki, żony i gospodyni domu. Niewątpliwym odzwierciedleniem takiego światopoglądu jest poradnik Józefa Legowicza Stan matżeński czyli prawidła szczęśliwego między matżonkami pożycia y porządnego a chrześciańskiego wychowania dziatek wydany w Wilnie w 1787 r.

Dzieło to idealnie wpisywało się w istniejący od doby renesansu nurt piśmiennictwa zwany ars bene vivendi, który to był opozycyjny w stosunku do bardziej znanego ars bene moriendi. Poradniki te nie prezentowały wzorów dobrego umierania, lecz miały na celu wskazanie takiej drogi życiowej, której obranie gwarantowało godziwe życie, a co za tym idzie i szczęśliwą wieczność po śmierci. Tego rodzaju opracowania w czasach nowożytnych cieszyły się ogromną popularnością. W ciągu tych trzech stuleci powstało wiele pism, traktatów i poradników, które wpisywały się w nurt piśmiennictwa parenetycznego. Można tu wspomnieć chociażby wcześniejsze dzieła Erazma Glicznera, Fabiana Birkowskiego, Stanisława Harolta, Mikołaja Jaśkiewicza czy Kaspra Chróścikowskiego ${ }^{3}$.

Sama nazwa paranetyka pochodzi od greckiego słowa paraneio, które oznacza zachęcam, namawiam, radzę, zalecam. Na piśmiennictwo tego typu składają się dwa zjawiska: po pierwsze to postawa parenetyczna, którą przyjmował autor tekstu wobec jego odbiorcy, starając się namówić go do proponowanych wartości i zachęcić do ich naśladowania, a po drugie to literatura parenetyczna, której nadrzędnym zadaniem było namówienie do przyjęcia określonego wzoru osobowego za pomocą specyficznych technik literackich ${ }^{4}$, m.in. perswazji. Parenetyka jako nurt literacki ma kilka cech charakterystycznych, ale najważniejszą wśród nich jest normatywizm (pedagogiczny), który to określa ideały osobowe i sposoby zachowania wzorcowych postaci w zależności od ich pozycji społecznej, przypisując im jednocześnie modelową hierarchię wartości ${ }^{5}$. Do tego nurtu zalicza się wiele form literackich, w tym: bajki, facecje, traktaty, jak również poradniki.

Wspomniany już wyżej J. Legowicz zaliczany jest do grona najpopularniejszych poradnikopisarzy XVIII w6 ${ }^{6}$. Wywodził się on z drobnej szlachty litewskiej, z województwa wileńskiego. Dokładna data jego urodzin nie jest znana, wiadomo natomiast, że 17 września 1768 r. wstąpił do seminarium duchownego, a dwa lata później otrzymał święcenia kapłańskie. Studiował także teologię na Uniwersytecie Wileńskim, który ukończył z tytułem doktora. W latach 70. XVIII w. został proboszczem wiejskiej parafii w Korkożyszkach7. Był

\footnotetext{
3 Więcej o tych (i innych) autorach oraz ich poglądach można się dowiedzieć m.in. z: E.E. Wróbel, Chrześcijańska rodzina w Polsce XVI-XVII wieku. Między ideałem a rzeczywistościa, Kraków 2002; B. Rok, Poradnictwo życiowe duszpasterzy czasów saskich, w: Rzeczpospolita wielu wyznań. Materiały z międzynarodowej konferencji. Kraków, 18-20 listopada 2002, red. A. Kaźmierczak [et al.], Kraków 2004, s. 311-320.

${ }^{4}$ H. Dziechcińska, Parenetyka, w: Stownik literatury staropolskiej, red. T. Michałowska, Wrocław 2002, s. $618-619$.

${ }^{5}$ H. Dziechcińska, Parenetyka - jej tradycje i znaczenie $w$ literaturze, w: Problemy literatury staropolskiej, red. J. Pelc, seria I, Wrocław 1972, s. 370.

${ }^{6}$ B. Rok, System wartości moralnych $w$ poradnikach dobrego życia $w$ XVIII wieku, w: Edukacja ku wartościom, red. A. Szerląg, Kraków 2004, s. 229.

${ }^{7}$ Oprócz nazwy Korkożyszki funkcjonują także Korkorzyszki, obie są poprawne i zamieszczone w Słowniku geograficznym Królestwa Polskiego i innych krajów słowiańskich, red. F. Sulimierski, B. Chlebowski, W. Walewski, t. 4, Warszawa 1883, s. 402.
} 
nim aż do 1812 r., kiedy to zmarł w wyniku pobicia. Po śmierci zaczął uchodzić za wzór kapłana-duszpasterza wiejskiego, przykład oświeconego duchownego ${ }^{8}$. Jego działalność pisarska obejmowała prace o charakterze poradników i kompendiów. Drukiem ukazało się kilkanaście jego pism, które dotyczyły różnych dziedzin życia - zarówno religijnego, jak i czysto praktycznych spraw gospodarskich, małżeńskich oraz rodzicielskich. J. Legowicz starał się wskazywać konkretne wzory dobrego żywota, zwracając przy tym uwagę na powinności poszczególnych stanów i profesji. Namawiał też szlachtę do zmiany stosunku wobec chłopów. Uważał, że trzeba zadbać o edukację ludności wiejskiej, gdyż ciemni i niewykształceni chłopi źle uprawiają ziemię?

Poradnik Stan matżeński... skierowany był przede wszystkim do ludności wiejskiej. Można jednak przypuszczać, ze względu na wskaźnik analfabetyzmu wśród chłopstwa w tym okresie, że autor, podobnie jak w przypadku pozostałych pism, zebrał te wiadomości dla powszechnej wiedzy innych wiejskich plebanów, aby ci mogli przekazać je dalej swym parafianom w ramach codziennej posługi duszpasterskiej. Poradnik ten składa się z dwóch części: pierwsza poświęcona została obowiązkom małżeńskim, a druga zatytułowana: O obowiąkach rodzicielskich, czyli prawidła dla rodziców fizycznego i moralnego, czyli co do ciała i duszy porzadnego a chrześcijańskiego wychowania dziatek traktuje o obowiązkach rodziców wobec dzieci w różnych fazach życia (od poczęcia do dorosłości) w celu ich prawidłowego wychowania i przygotowania do założenia własnej rodziny.

Jednym z najważniejszych celów sakramentu małżeństwa ${ }^{10}$ miało być powołanie na świat potomstwa. Zatem podstawowym zadaniem każdej kobiety będącej w związku małżeńskim było dopełnienie rodziny poprzez wydanie na świat dziecka. Zwłaszcza, że brak dziedzica mógł stanowić pretekst do wszczęcia procedury unieważnienia małżeństwa $^{11}$. Zważając na te okoliczności, nie może dziwić żywe zainteresowanie tym tematem wśród staropolskich pisarzy moralistów. Wspomniany już J. Legowicz w swym dziele wyróżnił dwa okresy powinności matczynych wobec dzieci: pierwszy - prenatalny, gdy kobieta była brzemienną i główne jej zadanie to donoszenie ciąży oraz urodzenie żywego, zdrowego potomka. Drugi następował już po narodzinach, a do obowiązków matki

\footnotetext{
${ }^{8}$ Oświecenie katolickie to nurt myśli oświeceniowej obecnej w XVIII-wiecznym Kościele Katolickim, która powstała w wyniku przenikania idei oświeceniowej propagowanej przez filozofów do scholastyki. Głównym celem było podniesienie moralne i intelektualne poziomu duchowieństwa, usprawnienia i ożywienia duszpasterstwa parafialnego, mecenat nad twórczością kulturalną oraz gromadzeniem bibliotecznych i rękopiśmiennych zbiorów.

9 Więcej w: B. Rok, Józef Legowicz - oświeceniowy kaznodzieja litewski próba szerzenia idei oświeceniowych wśród ludu, w: Oświeceni wobec rozbiorów Polski, red. J. Grobis, Łódź 1993, s. 245-262.

${ }^{10}$ Sobór trydencki zmienił podejście do małżeństwa i je usankcjonował. W trakcie dwudziestej czwartej sesji odbytej w listopadzie 1563 r. opracowano Doctrina de sacramento matrimonii, zwany inaczej Tametsi. Zawierał on cztery podstawowe prawdy wiary katolickiej o małżeństwie: 1. Jest to związek nierozerwalny, 2. Zawierany pomiędzy jedną kobietą i jednym mężczyzną, 3. Jest to źródło łaski uzyskanej dzięki męczeńskiej śmierci Chrystusa, 4. Małżeństwo uznano za sakrament.

11 Więcej w: I. Kulesza-Woroniecka, Rozwody w rodzinach magnackich $w$ Polsce XVI-XVIII wieku, Poznań-Wrocław 2002.
} 
należały wszelkie zabiegi cielesne i duchowe służące rozwojowi oraz wychowaniu dziecka na porządnego chrześcijanina.

Ksiądz Legowicz podkreślał, iż przyzwoitość tego wymagała, aby rodzice, zanim dojdzie do poczęcia, byli złączeni sakramentem małżeństwa, gdyż tylko ono miało moc legalizacji potomstwa. Matka i ojciec powinni także dbać o siebie i o swoje zdrowie zarówno fizyczne, jak i psychiczne (rozumiane w sensie duchowym). Autor powtarzał w tym zakresie zdanie lekarzy, że: umiarkowane życie we wszystkim prowadzić powinni, strzegąc się złych namiętności i zbrodni, pijaństw, opilstwa, cholery, smutku, melancholii, zbytnich prac etc. ${ }^{12}$. Przyszli rodzice winni także zdrowo i przyzwoicie się odżywiać, aby zwiększyć szansę na zapłodnienie, a następnie na donoszenie ciąży. Innymi ważnymi kwestiami poruszonymi przez autora były także: wiek małżonków (kobieta między 18-20. a 40., mężczyzna natomiast od 25. do 50. roku życia) oraz stan ich pożycia, które powinno odbywać się w zgodzie i wesołości. Zresztą podobne poglądy reprezentowane były i w innych państwach europejskich, wyrażał je chociażby dobrze znany w Polsce czeski pedagog - Jan Amos Komeński ${ }^{13}$.

Gdy tylko okazało się, że niewiasta jest w ciąży, powinna natychmiast powiadomić o tym swego męża, a następnie obydwoje zobowiązani byli do złożenia pokłonów dziękczynnych Bogu, który to obłaskawił ich tą dobrą nowiną. Od tego momentu codziennym obowiązkiem obojga małżonków było odmawianie modlitwy, w której prosiliby Boga o donoszenie ciąży oraz o łaskę chrztu świętego dla nowo narodzonego dziecka, ażeby zmyć z niego grzech pierworodny. I nie powinna dziwić taka rada, ponieważ w tamtych czasach powszechne były poronienia, dzieci urodzone przedwcześnie nie miały praktycznie żadnych szans na przeżycie, a fatalne warunki higieniczne mogły prowadzić niemowlęta do prędkiej śmierci ${ }^{14}$. Wysoka śmiertelność dzieci w pierwszych dniach życia tkwiła w dwóch głównych przyczynach: w wadach wrodzonych oraz chorobach i wypadkach, które nastąpiły już po porodzie. Szacuje się, że odsetek dzieci zmarłych w ciągu miesiąca po narodzinach wynosił ok. $12-15 \%{ }^{15}$.

Matka zatem, aby donosić ciążę terminowo, przez cały jej okres powinna mieć się na baczności i bardzo na siebie uważać, unikać wszelkich aktywności, które byłyby przyczyną utraty dziecka, gdyż brak jej ostrożności mógłby doprowadzić nie tylko do śmierci płodu, ale i męża (ze zgryzoty) ${ }^{16}$. J. Legowicz w swym poradniku wskazał dwanaście najważniejszych postulatów, do których powinna stosować się każda kobieta pragnąca urodzić zdrowe dziecko. Podzielić można je na kilka kategorii:

12 J. Legowicz, Stan matżeński, czyli prawidła szczęśliwego między mał̇̇onkami pożycia y porządnego a chrześciańskiego wychowania dziatek, oprac. B. Rok, w: Z podstaw poradoznawstwa, red. B. Wojtasik, z. 2 , Wrocław 1998, s. 99.

13 Jan Amos Komeński (1592-1670), czeski pedagog i filozof. Jako jeden z pierwszych podkreślał wartość samoistną dziecka, a dzieciństwo uważał za ważny etap w rozwoju w człowieka. Te i inne poglądy zawarł m.in. w dziele Pampaedia. Więcej zob.: E.E. Wróbel, op. cit.

14 D. Żołądź-Strzelczyk, Dziecko $w$ dawnej Polsce, Poznań 2002, s. 41-61.

${ }^{15}$ F. Lebrun, Jak dawniej leczono. Lekarze, święci i czarodzieje w XVII i XVIII wieku, Warszawa 1997, S. $135-136$.

16 J. Legowicz, op. cit., s. 99. 
a) pokarmy i napoje,

b) nadmierny wysiłek fizyczny,

c) odzienie,

d) emocje,

e) wypadki.

Po pierwsze białogłowa winna wystrzegać się obżarstwa, czyli niepomiarkowanego dziwactwa w pokarmie, tudzież jedzenia niestrawnych rzeczy, surowych, zbytnie stonych, zbytnie korzennych etc. ${ }^{17}$. Jest to wszakże nie tylko jeden $\mathrm{z}$ grzechów głównych, ale i mogło być to szkodliwe dla nienarodzonego jeszcze potomka, który przecież pobierał pokarm od matki, więc ta musiała się zdrowo i pożywnie odżywiać, aby i dziecku niczego nie zabrakło. Drugą rzeczą zabronioną było pijaństwo, opilstwo, jako i goracych trunków gęste używanie, które największa sa trucizna dla dziecka we wnętrznościach matki będącego ${ }^{18}$. Co ciekawe przyszła matka powinna wystrzegać się także (przez całą ciążę) zbyt mocnych zapachów, jednak autor nie wyjawił już, jaki motyw nim kierował przy formułowaniu tego zakazu.

Kolejną rzeczą, której zabraniał kobietom w ciąży w swym poradniku J. Legowicz była jazda konna i na trzeskich powozach, po drabinach chodzenie, przez płoty wysokie przechodzenie $^{19}$. Niewiasta $\mathrm{w}$ okresie ciąży nie powinna przesadnie się przemęczać, gdyż mogło to źle wpłynąć na rozwój jej dziecka. Winna unikać też zbytniego forsowania się pracą i braku snu po nocach. Z tą grupą czynności zabronionych związany był również zakaz dźwigania ciężarów. Autor autorytarnie nakazywał kobiecie zaniechanie wysokich śpiewów, krzyków i wszelkich innych wysiłków, których konsekwencją mogło być poronienie lub uszkodzenie płodu.

Ksiądz Legowicz sprzeciwiał się także sznurówka lub pasem zbytniemu ściskaniu się [...], oraz ciasnych sukien do nadziewania, obuwiów ciasnych z wysokiemi korkami ${ }^{20}$. Zauważył, że wiele kobiet (chcąc zachować piękną figurę bądź ukryć ciążę przed obcymi oczami) starało się jak najdokładniej schować pod ubraniami brzuch ciążowy lub obwiązać go czymś, co ściskało tak, aby nie był widoczny.

Do kategorii emocji można zaliczyć rady autora dotyczące zakazu lękania się, w górę podejmowania i ramion barzo podnoszenia [...] oraz zbytniego pragnienia rzeczy, wszelkiego zrażenia i gwałtownego zmieszania imaginacyi, jako też gniewu, cholery, irytacji, $\dot{z} a l u$, smutku, frasunku etc. ${ }^{21}$. J. Legowicz uważał, że gwałtowne uczucia targające przyszłą matką mogą zaszkodzić dziecku. Przecież oczywistym dla niego było, że negatywnie na rozwój malucha wpływało psucie krwi powstające w wyniku niepomiarkowanego gniewu i innych złych emocji szargających kobietą!

Ostatnim zagadnieniem, które poruszył ksiądz Legowicz w zakresie ciąży było ostrzeżenie przedstawicielek płci pięknej przed pośliźnieniem, upadnieniem, spadnie-

\footnotetext{
17 Ibidem, s. 100

18 Ibidem.

19 Ibidem.

${ }^{20}$ Ibidem.

${ }^{21}$ Ibidem.
} 
niem, zbiciem się, straceniem się, uderzeniem się etc. ${ }^{22}$. Wszelkie wypadki (czy to poważne, czy to tylko drobne) nie powinny zakłócać prawidłowego rozwoju dziecka.

Warto zaznaczyć, że rady dotyczące prawidłowego zachowania matki w ciąży, przestrzegania przez nią określonej diety i unikania nadmiernego wysiłku fizycznego pleban korkożyski formułował zarówno w oparciu o doświadczenie i tradycję, jak i na podstawie dorobku naukowego współczesnych mu lekarzy, w tym popularnego na ziemiach polskich Samuela Augusta Tissota ${ }^{23}$.

J. Legowicz nie zapomniał również o zbudowaniu wizji idealnej postawy moralnej ciężarnej. Według niego kobieta powinna godnie znosić wszelkie niedogodności związane z ciążą, a gdy objawy zanadto dokuczały, ratunkiem dla niej miało być oddawanie pokłonu sprawiedliwości Boskiej, poddajac się ochotnym sercem owej karze, która na nia $z s y ł a^{24}$. Ciężarna nie mogła zapomnieć również o spowiedzi (aby w przypadku śmierci mogła odejść z tego świata bez grzechu) oraz o regularnym przyjmowaniu hostii. Przeczuwając trudny poród, kobieta powinna w modlitwie obiecać Bogu zupełne posłuszeństwo jego woli. Nawet, gdyby bóle związane z dolegliwościami ciążowymi bądź porodem były nie do zniesienia, to nie godzi się $w$ żadnym przypadku nigdy matce dla uniknienia najdtuższej męczarni i ocalenia życia swojego brać takowych lekarstw, które by dziecku zaszkodzić mogły abo dopuszczać lub przyzwalać na to, co by mu zaszkodzić lub życie odjać mogło 25 .

Autor podkreślał wielokrotnie, że każda niewiasta (ze względu na wysoką śmiertelność przy porodzie i w połogu) powinna do rozwiązania szykować się jak do śmierci. Winna zachowywać się tak, jakby chciała przeżyć ostatnie dni swego życia i zrobić wszystko, czego tylko zapragnęła. Gdy już nieodległym stawał się termin porodu, każda chrześcijanka powinna zbliżyć się wówczas do Boga, a poprzez codzienną i coraz to gorętszą modlitwę prosić o łaskę życia zarówno dla siebie, jak i dla dziecka, a także o cierpliwość i zmniejszenie bólów porodowych. I nie było w tym nic dziwnego, ponieważ w całej Europie panowało powszechne przekonanie, najlepiej wyrażone w przysłowiu gaskońskim, że: Kobieta w ciąży jedna noga do grobu dąży ${ }^{26}$. Poród był bardzo niebezpieczny dla niewiasty. Urazy i wycieńczenie organizmu nim spowodowane mogły doprowadzić do różnych infekcji oraz gorączki połogowej, których efektem była nawet śmierć przy porodzie lub w ciągu miesiąca następującego po nim. Według szacunków badaczy w XVIII-wiecznej Francji umieralność okołoporodowa kobiet wynosiła do 7\% Fakt tak wysokiego odsetka śmiertelności związany był m.in. z komplikacjami pojawia-

22 Ibidem.

${ }^{23}$ Samuel Auguste Tissot (1728-1797), szwajcarski lekarz, neurolog. W swoich poglądach mieszał zabobonny tradycjonalizm z nowoczesnością. W zwalczaniu chorób stawiał na ziołolecznictwo i aromaterapię, podkreślał znaczenie samopoczucia i psychiki dla zdrowia. Jedną z jego najpopularniejszych książek w Rzeczypospolitej Obojga Narodów była Rada dla pospólstwa względem zdrowia jego z $1661 \mathrm{r}$.

\footnotetext{
${ }^{24}$ J. Legowicz, op. cit., s. 100

25 Ibidem, s. 101.

26 F. Lebrun, op. cit., s. 137.

27 Ibidem, s. 139-140.
} 
jącymi się w trakcie porodu, do których należy zaliczyć, np. nieprawidłowe ułożenie płodu. Dziś lekarze rozwiązują takie problemy cesarskim cięciem, które choć było już wtedy znane, to w praktyce stosowane bardzo rzadko. Powodem był brak obecności lekarza przy porodzie (wzywano go tylko w wyjątkowych sytuacjach), a akuszerki, będące na miejscu, nie posiadały odpowiednich umiejętności i przyrządów. Jednak przede wszystkim decydował o tym fakt, że był to zabieg bardzo niebezpieczny ${ }^{28}$.

Kolejną ze spraw okołoporodowych, o których wspomina autor poradnika było znalezienie doświadczonej akuszerki, która by pomogła przy odebraniu dziecka. Choć w wypadku ludności wiejskiej, do której skierowany był poradnik, bardziej na miejscu wydaje się używanie określeń: baba, dzieciobiorka czy pęporzezka ${ }^{29}$. J. Legowicz uważał, że trzeba włożyć wiele wysiłku w poszukiwanie odpowiedniej osoby, która byłaby bogobojna, a przy tym posiadała potrzebne umiejętności, albowiem niewiasty nieumiejętne podejmujace się przyjmowania dziatek niewymownie wielki grzech popetniaja i podlegają karom na zabójcę postanowionym ${ }^{30}$. Ksiądz Legowicz w swym poradniku pomimo poświęcenia wielu słów przygotowaniom, nie pokusił się już o próbę omówienia modelowego (oczywiście według niego) przebiegu porodu. Można w tym miejscu stwierdzić, że po prostu nie miał na czym oprzeć tego zagadnienia, ponieważ miejsce porodu w kulturze nowożytnej nie było przeznaczone dla mężczyzn, a już na pewno nie dla obcych mężczyzn! Świadczyć o tym może niewielkie zainteresowanie tej płci ginekologią i położnictwem, które zaczyna się dopiero rozbudzać w XVIII w. wraz z zakładaniem pierwszych klinik położniczych (1726 - Edynburg) oraz wprowadzaniem na uczelnie wyższe wykładów z zakresu położnictwa (1727 - Strasburg) $)^{31}$.

Kolejny rozdział autor zaczął od pierwszego podania dzieciątka na ręce matki, która po ujrzeniu swego potomka powinna od razu podziękować Bogu i jemu to dziecko ofiarować. Choć należy przy tym podkreślić, że wdzięczniejsza winna być nie za sam fakt urodzenia, ale za przeżycie dziecka do chrztu świętego, gdyż najważniejszą kwestią w pierwszych dniach życia nowo narodzonego człowieka było wprowadzanie go w poczet członków Kościoła. Ze względu na wysoką śmiertelność dzieci sakrament ten winien odbyć się jak najwcześniej. Sobór trydencki podtrzymał nakaz chrzczenia dziecka w ciągu kilku dni od porodu ${ }^{32}$ oraz potwierdził zasadę udzielania chrztu w kościele parafialnym. Ksiądz Legowicz (za postanowieniami synodalnymi) dopuszczał jednak możliwość samodzielnego ochrzczenia dziecka w domu przy porodzie za pomocą zwykłej, letniej wody, lecz tylko w wypadku, gdy istniało zagrożenie jego życia ${ }^{33}$. Gdyby jednak noworodek przeżył, ksiądz zalecał jak najszybsze ochrzczenie go w kościele.

\footnotetext{
${ }^{28}$ Historia medycyny, red. T. Brzeziński, wyd. 4, Warszawa 2014, s. 161-163.

29 D. Żołądź-Strzelczyk, op. cit., s. 41.

30 J. Legowicz, op. cit., s. 101.

${ }^{31}$ Historia medycyny..., s. 163.

${ }^{32}$ P. Hemperek, Chrzest dzieci w praktyce $i$ w prawodawstwie Kościoła katolickiego, „Roczniki Teologiczno-Kanoniczne" 29, 1982, z. 5, s. 45-57.

${ }^{33}$ Ksiądz Legowicz nie zapomniał przy tym o opisie całego rytuału: należało wziąć wody w naczynie, umoczyć pierwej głowę dziecięcia, tak żeby woda we chrzcie dotknąć mogła skóry samego ciała (i było praw-
} 
Do rodziców należało nadanie dziecku imienia. Jak pisała Dorota Żołądź-Strzelczyk imiona chrześcijańskie najczęściej wybierano z puli imion apostołów i ewangelistów, patronów państw słowiańskich, świętych oraz założycieli zakonów. Ciekawym wydaje się fakt, że większe przywiązanie do imion słowiańskich i pogańskich charakteryzowało szlachtę niż chłopstwo. Praktykowano różne zwyczaje nadawania imion, były one związane z: tradycjami rodzinnymi, dniem przyjścia na świat (wybierano wtedy patrona z kalendarza), w społecznościach wiejskich pomocą służył także pleban (lub sam wybierał imię w wypadku dzieci nieślubnych), a zdarzało się i przenoszenie na nowo narodzonego człowieka imienia jego wcześniej zmarłego rodzeństwa ${ }^{34}$. Ksiądz Legowicz proponował, aby rodzice nadawali swym potomkom imiona tych świętych, których cnoty podziwiali i następnie, aby dzieci w ten sposób wychowywali, żeby naśladowały one swych patronów. Do chrztu rodzice powinni ubrać syna lub córkę chędogo i porządnie [...], z zostawieniem otworzystości na barkach i piersiach na święte namaszczenia ${ }^{35}$.

Autor poradnika uważał, że wypielęnowanie niemowlęcia jest to urzad właściwy najbardziej samej matce ${ }^{36}$. Przecież dziecko głównie od niej zależało, przynajmniej do czasu odłączenia go od piersi. Z tego powodu ksiądz Legowicz sformułował także i zalecenia dla kobiet karmiących. Przy żywieniu dziecka piersią ważne było przestrzeganie przez matkę odpowiedniej diety. Autor powtarzał za lekarzami, że wszystkie te pokarmy $i$ napoje szkodliwe sq niewiastom rodzacym i połóg odbywajacym, które szkodliwe sq w goraczce zostającemu, jakiemi sa wszystkie pokarmy ostre, cierpkie, kwaśne, korzenne, niestrawne, wszystkie trunki, jako to: gorzałka, wino, miód, piwa świeże, chmielne, niewystane, mocne lub kwaśne (wyjąwszy lekki, czysty, wystaty i niechmielny podpiwek) ${ }^{37}$.

Ważne było stosowanie się do tych zaleceń, gdyż autor przestrzegal, że najwięcej matek z połogu umiera, gdyż te pokarmy oraz napoje śmiertelna gangrenę sprawiać zwy$k t y^{38}$. J. Legowicz ubolewał nad tym, że takie jedzenie i trunki podawane były zdecydowanie za często i to bez różnicy stanu społecznego, z którego wywodziła się matka. Autor zalecał kobietom w połogu jedzenie i picie, które pospolicie się dawać zwykły chorujacym na goraczkę, to jest pokarmy i napój nader lekkie, jakiemi sa kleiki z krup, lekkie buliony, woda wywarzona i osłodzona z włożeniem do niej osuszonej grzanki chleba, kasza krupiana, jęczmienna z młodym masłem, jajka miękko i rzadko gotowane lub polewka z jajek robiona. Niezdrowe są im oraz miód, cukry smażone, cukier i inne rzeczy lipkie $^{39}$.

Ksiądz Legowicz poza zaleceniami związanymi z dietą młodej matki, twierdził, że niewiasty odbywające połóg wszelkiej alternacyj wnętrzne, przerażenia się, przelęknienia

\footnotetext{
dziwe obmycie), potym lać wodę na glowę i razem mówić te slowa wyraźnie, żadnego z nich nie opuszczając: „Ja ciebie chrzczę w imię Ojca i Syna, i Ducha Świętego”, J. Legowicz, op. cit., s. 102.

${ }^{34}$ Więcej: D. Żołądź-Strzelczyk, op. cit., s. 78-83.

${ }^{35}$ J. Legowicz, op. cit., s. 101.

${ }^{36}$ Ibidem, s. 102.

${ }^{37}$ Ibidem.

${ }^{38}$ Ibidem.

${ }^{39}$ Ibidem, s. 102-103.
} 
etc., wczesnego do robót, prac i chodzenia, porywania się przez progi wysokie lub płoty tażenia etc., co wszystko jest dla nich wielkim niebezpieczeństwem strasznych przypadków, konwulsyj śmiertelnych i śmierci ${ }^{40}$ powinny unikać.

Samo karmienie piersią było jedną z najważniejszych kwestii poruszonych w poradniku. Autor uważał, że każda kobieta powinna samodzielnie karmić swoje dzieci, gdyż tak Bóg świat urządził, że najlepszym pokarmem dla niemowlaka jest mleko płynące z piersi matczynej, a nie innej niewiasty. J. Legowicz zalecał, aby dziecko karmione było piersią do około pierwszego roku życia, czyli momentu wyrośnięcia mu ząbków do gryzienia i wzmocnienia żołądka. Zresztą sam okres niemowlęctwa w czasach nowożytnych wyznaczany był na czas od porodu do odłączenia dziecka od piersi. Była to chwila wyjątkowa dla rozwoju i dalszych losów dziecka, świętowano ją bardziej uroczyście niż rocznice urodzin, a to ze względu na to, że wg szacunków ok. 25-30\% dzieci nie dożywało do tego momentu ${ }^{41}$.

Autor zauważył także, że karmienie piersią wpływa korzystnie na zdrowie kobiety, gdyż chroni ją przed długimi, ciężkimi i niebezpiecznymi chorobami występującymi u niewiast, które samodzielnie nie karmiły. Jednak, gdyby zdarzyło się tak, że niewiasta sama nie mogła karmić z powodu ważnych przyczyn, do których zaliczył choroby oraz następną ciążę, to wtedy powinna poszukać dla swej pociechy jak najlepszej mamki, która by ją na ten czas zastąpiła. Dobra mamka (podobnie jak i dobra akuszerka) winna być zdrowa, trzeźwa i bogobojna. Ponadto J. Legowicz wskazywał katalog innych jej przymiotów: 1. Twarz wesoła. 2. Dziąsła czerwone $i$ zdrowe, zęby czyste i białe (oprócz tego żeby nie miała jakiej choroby, np. kottunu etc.). 3. Apetyt dobry do jedzenia, bo to sa znaki pokarmu dobrego w jej piersiach dla dziecka. 4. Żeby miała łagodność, żywość i przyjemność. 5. Nie powinna być troskliwa, skłonna do pomieszania, smutku, cholery etc. Potrzeba, aby się kochała się $w$ ochędóstwie i nie była choleryczna ni barzo bojaźliwa. [...]. Powinna zdrowych zażywá pokarmów i prostych a łacnych do strawienia. Trunków mocnych ma się zawsze wystrzegać, bo te przepalaja pokarm. Powinna się zabawiać robota, ale bez zbytniego mordowania się $e^{42}$.

J. Legowicz znalazł w swym poradniku miejsce także i dla omówienia kwestii karmienia piersią w miejscach publicznych, jak i w domu. Według plebana przyzwoitość wymagała, aby kobiety ukrywały swój biust, powinny zatem nosić chusty wiązane na szyi. Zresztą nie tylko winny okrywać odsłonięte części swego ciała, ale dbać także i o to, aby dzieci zawsze były odziane. Przyczyną takiego zachowania powinien być wstyd przed patrzącymi z góry: Bogiem, aniołami i świętymi, ponieważ oni wszystko widzieli ze swych niebiańskich pozycji.

Kobiety winny także uważać na siebie, aby pokarm nie zepsuł się im w piersiach, co mogłoby być wynikiem przestraszenia lub innej zbytniej namiętności, a także przeziębienia i wypicia nadmiernej ilości trunków alkoholowych. Matki i mamki powinny chronić się przed przeziębieniem, gdyż to od nich właśnie dzieci przejmowały kaszel. J. Lego-

\footnotetext{
40 Ibidem, s. 103.

${ }^{41}$ F. Lebrun, op. cit., s. 135.

42 J. Legowicz, op. cit., s. 103.
} 
wicz i na to znalazł rozwiązanie: należało zadbać o obucie stóp - zwłaszcza w czasie jesiennych słot i zimowych mrozów. Autor wyznaczył także częstotliwość, z jaką kobieta powinna karmić swe potomstwo, otóż najlepiej raz na dwie godziny, ale za to niewiele naraz.

Do matki należało także utrzymywanie dziecka w jak największej czystości, bo to, prócz innych skutków, $w$ dziecku wesołość, rześkość i ukontentowanie sprawia ${ }^{43}$. Kobieta miała stać również na straży jego zdrowia. Według autora najszkodliwsze dla niemowląt były przekrzyczenia się, przepłakania, jako i stluczenia się, przełamania się, główki stracenia, stąd kalectwa garbatości, niemoty, głuchoty etc. ${ }^{44}$, co mogło w przyszłości wywołać jąkanie, ułomność lub niepełnosprawność. Matki powinny także uważać, aby dziecko (gdy zacznie już raczkować) nie zjadło ani ziemi, ani żyjących w niej robaków. Kobiety musiały też chronić potomstwo przed zmianami temperatur i przeciągiem, ponieważ mogły być przyczyną śmiertelnych chorób.

J. Legowicz uważał, że w żadnym wypadku niewiasty nie powinny na zbyt długo pozostawiać dzieci samych w domu, ażeby te nie stęsknity się i nie przepłakały się, bo ta matki powinna być zabawa, żeby swe niemowle rozweselała ${ }^{45}$. Dobre samopoczucie dziecku zapewniać miała (poza obecnością matki) jak najczęstsza zmiana pieluch. J. Legowicz był gorącym zwolennikiem tej idei, która pojawiła się dopiero w latach 60 . XVIII w.! Autor poradnika namawiał gorąco kobiety, aby przed kolejnym wykorzystaniem pieluch wyprały je dokładnie w czystej wodzie. Pomysły te jednak nie cieszyły się popularnością w szerokich kręgach odbiorców. Zwyczajowo utarło się, że zmieniać pieluchę należało raz lub góra dwa razy dziennie (przecież mocz nie był szkodliwy, w końcu stosowano go jako składnik w przeróżnych miksturach medycznych) i używać ich ponownie po wyschnięciu (bez uprzedniego wyprania) ${ }^{46}$.

Ksiądz Legowicz zakazywał kobietom, mimo ich jak najlepszych intencji, sypiania w jednym łóżku ze swym dziecięciem, ponieważ mogło się to okazać dla niego zbyt niebezpieczne! Autor pisał, że każde dziecko powinno mieć swoją kolebkę. J. Legowicz potępiał także szkodliwy w jego rozumieniu zwyczaj kołysania malucha do snu ${ }^{47}$. Za złe postępowanie uważał również ściskanie dzieci powijakami, czyli pasami lnianymi lub jedwabnymi, które krępowały ruchy niemowlaków, ponieważ wiązano je od stóp do szyi, więc wolna od nich była w zasadzie tylko główka ${ }^{48}$. Próbując wyplewić ten zwyczaj przywoływał cztery argumenty: 1. Że dziecko ciężko oddycha. 2. Że nie miewa należytej diestyi, czyli strawności [...]. 3. W dzieciach tych sposobem skrępowanych ostre cuchnie-

43 Ibidem, s. 104.

44 Ibidem.

45 Ibidem.

${ }^{46}$ F. Lebrun, op. cit., s. 134.

${ }^{47}$ Autor na poparcie swojej tezy przywoływał trzy argumenty: 1. Może się mózg skołatać dziecku, zbyt jeszcze delikatny na ten czas, lecz ani tym sposobem uśpić go można, co to go gluszy. 2. Sprawuje się womity, miesza się pokarm i zbija się będacy $w$ żoładku dziecka. 3. Stąd się rodza $w$ dziecięciu gwattowne wnętrzne boleści etc., J. Legowicz, op. cit., s. 104.

${ }^{48}$ D. Żołądź-Strzelczyk, op. cit., s. 102-108. 
nia z ust pochodzić zwykty. 4. Że dziecko przez daremne mordowanie się, żeby się rozwolnić, wysila się, słabiej, wrzeszczy, żółć psuje, złości nabiera etc. ${ }^{49}$. Do innych obowiązków matki autor zaliczył także, z jej szczerego oddania Bogu: nocne niespania, czułości, wstawania i najostatniejsze z doskonała cierpliwościa zmartwieniom goryczy i ciężkości osładzać sobie nadzieja wiecznej $w$ niebiesiech powinna zapłaty ${ }^{50}$.

Ksiądz Legowicz zdawał sobie sprawę z tego, że rola młodej matki jest ciężka. Doradzał więc, aby z każdym problemem i trudnością kobieta zwracała się bezpośrednio do Boga, który miał być jej duchową podporą moralną w ciężkich chwilach zwątpienia. Po odstawieniu dziecka od piersi rola matki odrobinę się zmniejszała, kobieta nie była już zobowiązana do bezustannego pilnowania potomka. Po zaprzestaniu karmienia w proces wychowania dziecka powinien włączyć się także i jego ojciec, a obowiązki względem potomka należało podzielić pomiędzy rodziców, ponieważ oboje winni dzielić trudy związane z dorastaniem dzieci. Autor wskazywał również, że we dwójkę mają obowiązek troszczyć się o rozwój zarówno duchowy, religijny, jak i fizyczny potomstwa.

Poradnik Józefa Legowicza adresowany do młodych oraz doświadczonych wiejskich rodziców, stanowi cenne źródło do postrzegania macierzyństwa i ojcostwa w kulturze staropolskiej oraz do historii wychowania końca XVIII w. Autor skonstruował bardzo rzeczowe i konkretne rady zarówno dla przyszłych, jak i świeżo upieczonych matek. Były one nowoczesne jak na swoje czasy, a wiele z nich nadal można uznać za aktualne. Za nowatorskie uchodzić może również, sygnalizowane w tym artykule, podejście do roli ojca, który powinien się włączyć w proces wychowawczy już w momencie odstawienia dziecka od piersi, a nie jak tradycyjnie przyjmowano dopiero od postrzyżyn (i to tylko w stosunku do syna). J. Legowicz był także zwolennikiem i propagatorem idei powstałych pod wpływem oświecenia, m.in. w zakresie higieny i potrzeb dziecka. Autor w swym poradniku poruszył nie tylko omówiony w artykule wątek początków życia dziecka, ale w dalszej narracji także i sposoby wychowania go (oczywiście w duchu wiary katolickiej) na porządnego człowieka, przygotowanego do pełnienia w dorosłym życiu przeznaczonych mu ról społecznych typowych dla omawianej epoki.

\section{Bibliografia}

\section{Źródło}

Legowicz J., Stan małżeński, czyli prawidła szczęśliwego między matżonkami pożycia y porządnego a chrześciańskiego wychowania dziatek, oprac. B. Rok, w: Z podstaw poradoznawstwa, red. B. Wojtasik, z. 2, Wrocław 1998.

\footnotetext{
49 J. Legowicz, op. cit., s. 104.

${ }^{50}$ Ibidem.
} 


\section{Opracowania}

Bartnicka K., Księdza Józefa Legowicza poradnik życia rodzinnego, „Przegląd Humanistyczny”, nr 4, Warszawa 1993.

Bednarek A., Legowicz Józef, w: Encyklopedia katolicka, t. X, Lublin 2004.

Bogucka M., Białogłowa w dawnej Polsce, Warszawa 1998.

Bogucka M., Gorsza płeć. Kobieta w dziejach Europy od antyku po wiek XXI, Warszawa 2005.

Dziechcińska H., Kobieta w życiu i literaturze XVI i XVII wieku, Warszawa 2001.

Dziechcińska H., Parenetyka - jej tradycje i znaczenie w literaturze, w: Problemy literatury staropolskiej, red. J. Pelc, seria I, Wrocław 1972.

Dziechcińska H., Parenetyka, w: Stownik literatury staropolskiej, red. T. Michałowska, Wrocław 2002.

Historia medycyny, red. T. Brzeziński, wyd. 4, Warszawa 2014.

Kobiety o kobietach. Studia i szkice średniowiecze i czasy nowożytne, red. W. Zawitkowska, Rzeszów 2010.

Kulesza-Woroniecka I., Rozwody w rodzinach magnackich $w$ Polsce XVI-XVIII wieku, PoznańWrocław 2002.

Lebrun F., Jak dawniej leczono. Lekarze, święci i czarodzieje w XVII i XVIII wieku, Warszawa 1997.

Rok B., Józef Legowicz - oświeceniowy kaznodzieja litewski próba szerzenia idei oświeceniowych wśród ludu, w: Oświeceni wobec rozbiorów Polski, red. J. Grobis, Łódź 1993.

Rok B., Polskie poradniki dobrego życia w XVIII w. - poszukiwanie inspiracji wspótczesnego poradnictwa, w: Poradnictwo w okresie transformacji kulturowej. Materiały VI Ogólnopolskiego Seminarium Naukowego Wrocław, 20-22 września 1993 r., Wrocław 1995.

Rok B., Poradnictwo życiowe duszpasterzy czasów saskich, w: Rzeczpospolita wielu wyznań. Materiaty z międzynarodowej konferencji Kraków 18-20 listopada 2002, red. A. Kaźmierczak [et al.], Kraków 2004.

Rok B., System wartości moralnych w poradnikach dobrego życia w XVIII wieku, w: Edukacja ku wartościom moralnym, red. A. Szerląg, Kraków 2004.

Rok B., Wyobrażenie matżeństwa w kulturze Wielkiego Księstwa Litewskiego u schyłku XVIII w. Poradnik pożycia malżeńskiego Józefa Legowicza z 1787 roku, w: Wileńszczyzna mata ojczyzna, red. A. Szerląg, Wrocław 2010.

Roztworowski E., Legowicz Józef, w: Polski słownik biograficzny, red. E. Roztworowski, t. 17, Wrocław 1972.

Słownik geograficzny Królestwa Polskiego i innych krajów słowiańskich, red. F. Sulimierski, B. Chlebowski, W. Walewski, t. 4, Warszawa 1883.

Wróbel E.E., Chrześcijańska rodzina w Polsce XVI-XVII wieku. Między ideałem a rzeczywistościa, Kraków 2002.

Żołądź-Strzelczyk D., Dziecko w dawnej Polsce, Poznań 2002. 